\title{
THE EFFECT OF USING LKPD BASED OF PROBLEM BASED LEARNING MODEL ON IMPROVING THE ABILITY OF STUDENTS' MATHEMATICAL COMMUNICATION
}

\author{
Hany Zahira ${ }^{1}$, Zulkarnain ${ }^{2}$, Putri Yuanita ${ }^{3}$ \\ Universitas Riau, INDONESIA
}

\section{ARTICLE'S}

INFORMATION

\section{Article history:}

Received: Aug-16-2020

Accepted: Dec-30-2020

Keywords: LKPD PBL,

Mathematical

Communication Ability

\section{Corresponding address:}

Hany Zahira,

\begin{abstract}
This research aims to know the effect of using LKPD based of Problem Based Learning model in improving Mathematical Communication Ability of Grade VIII Students at Dwi Sejahtera Junior High School Pekanbaru. The type of this research was Quasi Experimental Research with pretest-posttest control group design. The population was all students of Dwi Sejahtera Junior High School Pekanbaru Academic Year 2019/2020. The samples selection was conducted by using random sampling technique. Based on the result of data analysis, obtained the average score of posttest in Experimental Class 90,87, and the average score of the Control Class is 48,67. It means the average of Experimental Class is higher than the Control Class. The difference test of both averages used t-test obtained significance (2tailed) $0,000<\alpha=0,05$ which means the average of posttest score of students' Mathematical Communication Ability who learn by using LKPD based of PBL is different from the average score of posttest of students' Mathematical Communication Ability who learn by using scientific learning model. Thus, it can be concluded that there is effect of Problem Based Learning model on students' Mathematics Communication Ability.
\end{abstract}

E-mail: hanyzahira6391@gmail.com

\section{INTRODUCTION}

Mathematics is a branch of science that has an essential role in the life. Many activities undertaken by the individual, it is related to mathematics. Such as buying and selling, the problem of building engineering, measurement problem and others. The important role of mathematics for life is to answer issues in everyday life, it is due to mathematics is a basic science for the implementation in other fields [1]. Therefore, every student, from elementary till high school and college, should master mathematics. Learning mathematics in schools is inseparable from the regulated curriculum. The implementation ofmathematics in the scool of Indonesia is currently regulated in the Curriculum 2013. In the annexes of Permendikbud Number 58 of 2014 concerning the Junior High School curriculum, it is explained that one of the objectives oflearning mathematics is communicating the ideas, reasoning and being able to compile mathematical evidence by using the complete sentences, symbols, tables, diagrams, or other media to clarify the situation or problem.

This is in accordance with the process standards set by NCTM, in which the abilities that students must be owned to achieve content standards including problem solving skills, reasoning and proof,communication, connectionand representation [2]. Based on this regard, the mathematical communication cannot be separated from learning mathematics. According to Sumarmo, mathematical communication activities include of : (a) Expressing a situation, picture, diagram, or real object into language, symbols, ideas, or mathematical models; (b) Explaining ideas, 
situations, and mathematical relations orally or in writing; (c) Listening, discussion and writing about mathematics; (d) Reading with the understanding of a written mathematical representation; (e) Reexpressing a description or paragraph of mathematics into the own language [3].

Mathematical communication skills are closely related to representing mathematical ideas and symbols that are important to be applied in solving mathematical problems. Without a good communication, mathematical development will be hampered. However, in reality, the communication skills of students in Indonesia are still low. The result of PISA in 2015 declared that Indonesia was ranked 64th out of the following 65 countries with a score of 375 out of an international average of 494.Based on the study of PISA, communication skills are one of the important abilities that must be considered. Mathematical communication skills that are meant by PISA are understanding in writing, oral or graphical communication regarding mathematical communication problems, and the ability to express mathematical thinking seen in the various ways [4]. The low mathematical communication skills of students can also be seen from the results of the National Examination. In the Republika news, the results of a 2003 survey by the National Center for Education Statistics (NCES) on Indonesian student achievement revealed that Indonesian student achievement was ranked 39th out of 41 countries [5].

This data supported by the results of the 2016 Middle School National Examination which showed that the lowest average UN score was in Mathematics. The results of observations carried out by the researcheron some students of VIII grade junior high school in Pekanbaru, it indicated that the mathematical communication skills were still low. When they were given a number of questions, students did not understand the writing of mathematical symbols, students had difficulty changing story problems into mathematical sentence forms, students did not understand the meaning of variables, it was difficult to draw well and had not been able to give conclusions from a mathematical problem. Mathematic is an abstract science, which uses a lot of confusing symbols and formulas. Soedjadi expressed that students' perceptions of mathematics as a difficult subject, allowing students to make mistakes in solving problems [6].

Further, to understand both oral and written questions related to everyday problems. Students are not trained to communicate ideas / ideas in its solving. Evidence of errors occurs in the prerequisite aspect in which students cannot change the story problem into a mathematical model.In addition, the lecture method that is often used by teachers in learning, it tends to make students learn abstract concepts, without going through the process of use or without experiencing concrete references [7]. The learning tends to receive knowledge and it does not build knowledge on its own. The domination of the teacher towards learning will make students to be passive and lose the opportunity to explore the knowledge that they want to gain. The teaching materials used by the teacher, such as textbooks, it contains more material and routine questions, so that students are not trained to find out their own knowledge and are only recipients of information.

As a result, student's understanding of the teaching material often does not meet with the expectations and objectives of the learning that they want to achieve. So that, it will also have an impact on mathematical communication skills. There is a need for other teaching materials to support textbooks such as LKPD. However, the LKPD received by students from schools is in the form of LKPD that are sold from publishers. LKPD has not been able to construct the knowledge of students because the contents are in the form of copies of material and questions. To overcome this problem, the role of the teacher in choosing learning models and teaching materials needs to be considered so that the objective of mathematics is to increase mathematical communication skills. The learning model used by the teacher must be able to make students link to the 
mathematical problems in the form of mathematical sentences, symbols or pictures. One of the learning models that can develop students' abilities to interpret a problem into the mathematical form properly is Problem Based Learning. PBL is a learning using problems related to the real world. This problem is raised so that students can understand problems, develop the ability to convey information or communicate ideas, analyze and evaluate mathematical thinking, and draw conclusions from what has been learned. To support the implementation of the PBL learning model, it is accompanied by LKPD.

Based on Permendikbud Number 8 of 2016, a good LKPD leads to an active learning process, such as asking and answering questions both independently and in groups so that an active learning atmosphere can be created, it is not only questions that students must complete it. It is better if LKPD is adjusted to the learning model used by the teacher. The LKPD based PBL is a teaching material designed to incorporate the steps of PBLin the LKPD. So that, it can assist the students in the learning process, especially in constructing students' knowledge. LKPD begins with the problem orientation stage, namely giving the contextual question, the stage of organizing students, namely communicating the information on the questions, the guiding stage of the investigation, namely solving the questions, the presenting stage, namely communicating verbally the results of the answers to questions and concluding. Students follow the steps of PBLin the LKPD to train knowledge building.

In the research of Risfalidah, Rosidin, \& Sutiarso, it was seen that the results of students' mathematical communication skills through learning usingbased LPKD based PBL were able to optimize the competence of students so that they could better understand and understand the content of the material [8]. Students communicate their knowledge in writing on the LKPD. In the learning process, students are still confused by beingpresented LKPD directly.

However, the teacher provides guidance at the early stages of learning, further, slowly, the teacher reduces it to give students the opportunity to do their own assignments. When the students have carried out their responsibilities in those tasks, so then, the teacher begins to reduce the assistance, it aims to students can work independently. With a quality and well prepared LKPD, it is expected that the learningprocess becomes meaningful and ultimately the students' mathematical communication skills will increase. Dealing with the problem identification above, the aim of this research is to find out the effect of using LKPD based PBL on students' mathematical communication skills. Then, it has been tested the validity and practicality of LKPD used.

\section{METHODS}

The type of this research was a quasi-experimental with the research design of pretest posttest control group design. This research was conducted in two classes, namely the experimental class and the control class. Before the treatment, both classes were given a pretest to discover their initial ability. The treatment was given to the experimental class using LKPD based on the PBL model and in the control class with scientific learning. After being given treatment, the two classes will be given a posttest to discover the final ability of the material that is assessed in accordance with the indicators of mathematical communication skills. The population of this research were all students of SMP Dwi Sejahtera Pekanbaru in the even semester of the 2019/2020 school year. Sampling in this research was a random sampling technique that was carried out by randomly taking 50 students. The instrument used in this research was a test. The test used in this research was an essay test of 4 questions. The essay test was prepared based on the indicators of mathematical communication skills that will be observed. In one question can have one or more indicators. 
Several indicators of mathematical communication skills based on the reason of suitability on the research material, namely the material of SPLDV in the class VIII SMP.

The indicators were as follows:

1. Declare the event everydayin language or mathematical symbol.

2. Explain mathematical ideas, situations and relations orally or in writing with real objects, pictures, graphics, and algebra.

3. Describe the situation of a problem into pictures, tables, diagrams, or graphs.

4. Provide conclusions on the solutions that obtained.

In this research, the data obtained from the pretest and posttest experimental class and control class. The pretest results will be analyzed by looking at the average experimental class and control class. If the average of the two classes is the same or almost the same, then the students' initial abilities are the same. Thus, to discover the effect of a treatment by analyzing the posttest results of the experimental class and the control class. However, if the average experimental and control class differ greatly so that the initial ability of students in the two classes is different. Then, to see the effect of a treatment by calculating the difference between the pretest and posttest results in experiment class. To know the effect of treatment based on its significance is using the statistical test of parametric or the statistical test of nonparametric. If there is a significant difference between the experimental group and the control group, then the treatment given has a significant effect.

\section{RESULTS AND DISCUSSION}

The results of the pretest descriptive analysis obtained an average of 39.29 in the experimental class meanwhile the control class was 41.33. It indicates that the pretest average of the two classes is almost same. While based on the results of the Independent Samples Test sig. ( 2 tailed) obtained $0.269>0.05$ then the selection of the basis for decision making is that there is no difference in the initial mathematical communication skills of students in the experimental class and the control class, so post-test data is used to determine whether or not there is a mathematical communication ability between students who use learning tools developed with students who do not use the learning tools developed. Before the analysis is carried out to discover the effect of the treatment, the prerequisite analysis istested first in which it consists of the normality test and the homogeneity test.

1. The Result of Normality Test

The normality test on the posttest data for the experimental and control classes used the Kolmogorov-Smirnov test through SPSS. The calculation result of the normality is presented in Table 1 below.

Table 1. Normality Test of Posttest Values for Experiment and Control Class

\begin{tabular}{lllccl}
\hline Class & $\boldsymbol{N}$ & Mean & SD & Sig. & Conclusion \\
\hline Experiment & 24 & 90,87 & 9,11 & 0,37 & Normal \\
Control & 25 & 48,67 & 6,62 & 0,71 & Normal \\
\hline
\end{tabular}

If the significant value of $\mathrm{K}-\mathrm{S}>$ on the alpha significance level is $5 \%$, it can be concluded that the data is normally distributed. Conversely, if the significant value of $\mathrm{K}-\mathrm{S}<$ on the alpha significance level is $5 \%$, it can be concluded that the data are not normally distributed. Based on Table 1, the pretest data shows that for the experimental class the significance level $\mathrm{P}>\propto$ is $0.37>$ 0.05 and the significance for the control class level is $\mathrm{P}>\propto 0.71>0.05$. Thus, it can be concluded that $\mathrm{H}_{0}$ is accepted, it implies that the data variance of the experimental class and control class isdistributed normally. 


\section{The Result of Homogeneity Test}

The homogeneity test is one of the requirements that must be met before conductingthe difference test ofthe two means. The homogeneity test was carried out to determine whether the experimental class and the control class had the same variance (homogeneous) or not before getting different treatments. The results of the post-test data homogeneity test for the experimental class and control class are shown in Table 2 below.

Table 2.Homogeneity Test on Posttest Value for Experiment and Control Class

\begin{tabular}{lccccc}
\hline \multicolumn{1}{c}{ Class } & $\boldsymbol{N}$ & Mean & SD & Sig. & Conclusion \\
\hline Experiment & 24 & 90,87 & 9,11 & \multirow{2}{*}{0,10} & \multirow{2}{*}{ Homogenous } \\
\hline Control & 25 & 48,67 & 6,62 & & \\
\hline
\end{tabular}

Based on Table 2, for the post-test data of the experimental class and the control class the significance level is obtained $\mathrm{p}>\propto=0.05$. It can be concluded that $\mathrm{H}_{0}$ is accepted, it implies that the variance of the post-test data for the experimental class and control class is homogeneous. It is due to the data for the two classes are not distributed normally, to find out whether there is or not a significant difference between the experimental and control classes, it is followed by a statistical test, namely the $t$ test. The results of the t-test calculation of the post-test value are shown in Table 3 below.

Table 3.Test Results of the Two-Mean Difference Test (t-test) Posttest for the experimental and control classes

\begin{tabular}{lccccc}
\hline \multicolumn{1}{c}{ Class } & $\boldsymbol{N}$ & Mean & SD & Sig, & Conclusion \\
\cline { 1 - 3 } Experiment & 24 & 90,87 & 9,11 & \multirow{2}{*}{0,00} & \multirow{2}{*}{$H_{0}$ rejected } \\
\hline Control & 25 & 48,67 & 6,62 & & \\
\hline
\end{tabular}

Based on Table 3, for the posttest data for the experimental class and control class, the significance level is obtained $\mathrm{p}<=0.05$. Hence, it can be concluded that $\mathrm{H}_{0}$ is rejected, it implies that there is a difference in the results of the posttest of the experimental class and the control class. Thus there is a difference in mathematical communication skills between students who use developed learning media and students who do not use the developed learning media.

According to Prastowo, LKPD is a printed teaching material containing the sheets are arranged sequentially, summaries and instructions for implementing learning [9]. Good LKPD is one that can construct student knowledge and can assist achieve learning goals. Meanwhile, PBL is a learning model that begins with the provision of a contextual problem related to learning material. Students are asked to solve problems without being given by material. This means that students will construct their knowledge to solve these problems. By using PBL-based LKPD, students' learning becomes structured and active. The result of Hani Ervina Pansa's research showed that the LKPD developed was effectively used to improve mathematical communication skills by looking at the percentage of students who passed the KKM was $80 \%$ [10]. This means that the percentage of pass grade is more than $70 \%$.

In other words, after learning using LKPD with the PBL model, students' mathematical communication skills have reached the minimum completeness criteria. Some students also argue that through presenting problems related to the real world, it could make them enthusiastic about learning, because lesson is not only concerned on memorizing the formula. It is in line with Kodariyati and Astuti, which indicated that the use of PBL-based LKPD affected students' mathematical communication skills [11]. The result of the $\mathrm{N}$-gain calculation, the probability value (Sig.) was less than 0.05.This means that the null hypothesis is rejected. Thus, it can be concluded 
that there is a significant difference between the increase in the mathematical communication skills of students who join the learning through LKPD based PBL and students who join the learning throughusing conventional learning. Considering to gain index that obtained by the average gain index of mathematical communication of students in the two classes that is different, the average communication gain index of students who join learning using LKPD based PBL is higher than the average communication gain index of students who join conventional learning.

This shows that the increase in the communication skills of students who join learning using LKPD based PBL is higher than the increase in the communication skills of students who join conventional learning. In Wardani and Merona's research [2], after implementing a problem-based learning model with 5 stages, there was an increase in mathematical communication of class VII B students at MTs Ma'arif Balong Ponorogo. The increaseknown from the average percentage of tests in the first cycle was 59\% in the sufficient category and in the second cycle increased to $80 \%$ in the good category.

The PBL stages used by Wardani and Merona are the same as those used by researchers, namely:

1. Orientation the students on the problem.

2. Organizing the students to learn.

3. Guiding individual investigation.

4. Developing and presenting the work.

5. Analyzing and evaluating the problem-solving process.

This stage is the same as the stages in the LKPD that researcher uses. Stages one to three are found in the LKPD, step four, students undertake presentation in front of the class and stage five, the teacher and students evaluate the problems that have been answered previously. Presentation activities can train students to dare to speak in front of others and can develop their verbal communication skills to explain the results of their discussions and respond to the work of other groups [11]. This leads to the communication skills of students can be formed through the implementation of a problem-based learning model in the learning process.

On the whole, the stages in problem-based learning were more likely to enable the students to communicate mathematically [12]. So that, it is undeniable that the mathematical communication skills of students who take problem-based learning develop more optimally than the mathematical communication skills of students who take conventional learning. Therefore, it can be indicated that the problem based learning model will affect the mathematical communication skills of students.

\section{CONCLUSIONS AND SUGGESTIONS}

Based on the results of the research, it can be concluded that there is effect of using LKPD based of problem based learning on students' communication ability. It means that the usage of this LKPD based of PBL is effective for improving Mathematical communication. The result of this research is expected to be the reference for other researchers in conducting the research in the same scope.

\section{THANK-YOU NOTE}

In completing this article, researcher get a lot of guidance, direction, motivation and prayers from various parties. Therefore, researcher would like to thank the parties are Mr. Dr. Zulkarnain, M.Pd, as a supervisor I and Mrs. Dr. Putri Yuanita M.Ed as the second counselor who has provided guidance and direction to researcher. 


\section{REFERENCE}

[1] D. A. Sholihah and A. Mahmudi, "Keefektifan Experiental Learning Pembelajaran Matematika MTs Materi Bangun Ruang Sisi Datar," J. Ris. Pendidik. Mat., vol. 2, no. 2, pp. 175-185, 2015.

[2] V. N. Wardani and S. P. Merona, "Implementasi Model Pembelajaran Berbasis Masalah Untuk Meningkatkan Komunikasi Matematis Siswa," J. Silogisme Kaji. Ilmu Mat. dan Pembelajarannya, vol. 1, no. 2, pp. 34-40, 2016.

[3] A. Yuliani, "MENINGKATKAN KEMAMPUAN KOMUNIKASI MATEMATIK PADA MAHASISWA MELALUI PENDEKATAN CONTEXTUAL TEACHING AND LEARNING (CTL)," Infin. J., vol. 4, no. 1, pp. 1-9, 2015.

[4] OECD, "Retrieved from What Students Know and Can Do Student Performance in Matehmatics, Read-ing, and Science," 2016. .

[5] Y. M. P. Putra, “Nilai Matematika Paling Turun pada UN 2016," Jun-2016.

[6] L. Moma, "Analisis Kesalahan Siswa Kelas VI SD dalam Menyelesaikan Soal Pengukuran Panjang," J. MIPA, vol. 1, no. 2016, 14AD.

[7] U. Khasanah and Sutama, "Kesulitan Menyelesaikan Soal Cerita Matematika pada Siswa SMP," Pros. Semin. Nas. Pendidik. Mat. UMS 2015, 2015.

[8] Risfalidah, U. Rosidin, and S. Sutiarso, "PENGEMBANGAN LKPD BERBASIS PROBLEM BASED LEARNING DITINJAU DARI DISPOSISI DAN KEMAMPUAN KOMUNIKASI MATEMATIS," J. Penelit. dan Pembelajaran Mat., vol. 12, no. 2, pp. 271-283, 2019.

[9] T. Agustina, I. K. Suastika, and D. Triwahyuningtyas, "Pengaruh Penggunaan Lembar Kerja Peserta Didik (LKPD) Berbasis Contextual Teaching And Learning (CTL) Terhadap Hasil Belajar Siswa Materi Lingkaran Kelas 5 SDN Tanjungrejo 2 Malang," in Seminar Nasional PGSD UNIKAMA, 2019, pp. 238-248.

[10] H. E. Pansa, Caswita, and S. S, "Pengembangan LKPD dengan Model Problem Based Learning untuk Meningkatkan Kemampuan Komunikasi Matematis Siswa," Pendidik. Mat. FKIP Univ. Lampung, vol. 1, no. 1, pp. 229-238, 2017.

[11] L. Kodariyati and B. Astuti, "Pengaruh Model PBL Terhadap Kemampuan Komunikasi dan Pemecahan Masalah Matematika Siswa Kelas V SD," J. Prima Edukasia, vol. 4, no. 1, pp. 93-106, 2016.

[12] Fitriyanti, S. H. Noer, and P. Gunowibowo, "Pengaruh Model Problem Based Learning Terhadap Kemampuan Komunikasi Matematis dan Self Confidence," J. Pendidik. Mat. Univ. Lampung, vol. 4, no. 1, pp. 1-10, 2016.

\section{BIOGRAPHY}

Hany Zahara

She was born in the city of Medan on Wednesday, March 6, 1991. Researcher completed her Strata1 (S-1) in 2013 and strata-2 (S-2) in 2020. Phone Number 082384276793 and email hanyzahira6391@gmail.com

Zulkarnain

Lecturer in the Universitas Riau. He obtained his Strata-3 (S3) in Universiti Kebangsaan Malaysia. Email: zulkarnainfkip@lecturer.unri.ac.id

Putri Yuanita

Lecturer in the Universitas Riau. She obtained her Strata-3 (S3) in Universiti Kebangsaan Malaysia. Email: putri.yuanita@lecturer.unri.ac.id 